\title{
Proceeding
}

Supplementary Issue: Winter Conferences of Sports Science. Costa Blanca Sports Science Events, 24 April 2020. Alicante, Spain.

\section{The beneficial effects of physical activity and weight loss on human colorectal carcinoma cell lines}

RITA POLITO ${ }^{1}$, ALESSIA SCARINCI ${ }^{2}$, ANTONIO AMBROSI ${ }^{3}$, NICOLA TARTAGLIA ${ }^{3}$, DOMENICO TAFURI ${ }^{4}$, MARCELLINO MONDA ${ }^{5}$, ANTONIETTA MESSINA ${ }^{5}$, FABIANO CIMMINO$^{6}$, ANGELA CATAPANO ${ }^{6}$, FRANCESCO SESSA ${ }^{1}$, GIROLAMO DI MAIO ${ }^{5}$, VINCENZO CRISTIAN FRANCAVILLA ${ }^{7}$, GIOVANNI MESSINA ${ }^{1}$, VINCENZO MONDA $^{5}$

${ }^{1}$ Department of Clinical and Experimental Medicine, University of Foggia, Italy

2Department of Education, Psychology, Communication, University of Bari, Italy

${ }^{3}$ Department of Medical and Surgical Sciences, University of Foggia, Italy

${ }^{4}$ Department of Motor Sciences and Wellness, University of Naples "Parthenope", Naples, Italy

${ }^{5}$ Department of Experimental Medicine, Section of Human Physiology and Unit of Dietetic and Sport Medicine, University of Campania Luigi Vanvitelli, Naples, Italy

${ }^{6}$ Department of Biology, University of Naples Federico II, Naples, Italy

${ }^{7}$ School of Engineering, Architecture, and Motor Sciences, Kore University of Enna, Enna, Italy

\begin{abstract}
Recent studies have demonstrated that obesity is a significant risk factor for the development of several malignancies such as cancer. Colorectal cancer is among the most common cancers worldwide and is strong linked to obesity. A healthy lifestyle, characterized by hypocaloric diet and physical activity, is important to reduce a chronic inflammation, oxidative stress and metabolic disorders typical of obesity (Messina et al, 2018; Messina et al, 2017; Messina et al, 2015). It is well known that the chronic inflammation state and oxidative stress are responsible for the aging and development of many diseases, such as cancer. Dysregulation of cytokine's secretion probably participates in the establishment of cancer in obese patients. The aim of this study is to analyse the effects of sera from obese patients subjected to a physical activity program before and after weight loss on cell viability, apoptosis and oxidative stress in HCT116 carcinoma cell line treated for 24, 48 and 72 hours through MTT test. We analysed the expression of cytokines in HCT116 cells. We found that sera from obese after physical activity intervention compared to treatment with sera from obese patients before physical activity intervention reduce the survival rate of HCT116 cells through induction of apoptosis and oxidative stress. Finally, we found a reduction of mRNA levels corresponding to the pro-inflammatory IL-6 and IL-8 cytokines together with an increase of the anti-inflammatory IL-10 cytokine. We can conclude that the physical activity has numerous beneficial effects also in colorectal cancer cell, indeed the physical activity and weight loss in obese subjects have an inhibitory and anti-inflammatory effects in a short period on carcinoma cell line.
\end{abstract}

Keywords: Physical activity; Obesity; Colorectal cancer; IL-6; IL-8; IL-10.

\section{Cite this article as:}

Polito, R., Scarinci, A., Ambrosi, A., Tartaglia, N., Tafuri, D., Monda, M., Messina, A., Cimmino, F., Catapano, A., Sessa, F., Di Maio, G., Francavilla, V.C, Messina, G., \& Monda, V. (2020). The beneficial effects of physical activity and weight loss on human colorectal carcinoma cell lines. Journal of Human Sport and Exercise, 15(2proc), S252-S260. doi:https://doi.org/10.14198//hse.2020.15.Proc2.16

Corresponding author. Department of Experimental Medicine, Section of Human Physiology and Unit of Dietetic and Sport Medicine, University of Campania Luigi Vanvitelli, Naples, Italy.

E-mail: vincenzo.monda@unicampania.it

Supplementary Issue: Winter Conferences of Sports Science. Costa Blanca Sports Science Events, 24 April 2020. Alicante, Spain.

JOURNAL OF HUMAN SPORT \& EXERCISE ISSN 1988-5202

(c) Faculty of Education. University of Alicante

doi:10.14198/jhse.2020.15.Proc2.16

S252

| 2020 | Proc2 | VOLUME 15

C 2020 University of Alicante 


\section{INTRODUCTION}

Obesity is the serious problem and it has an important impact on public health. This disease is characterized by many factors such as energy imbalance, due to that energy intake exceeds energy expenditure and such as deregulation of other metabolic parameters as worse lipid profile, increased insulin resistance and a chronic pro-inflammatory state (Bray et al., 2017). It is well known that in obese subjects there is an accumulation of visceral adipose tissue in the abdominal area of the body. The accumulation of visceral adipose tissue is dangerous because it induces an imbalance in endocrine mediators such as adipokines and pro-inflammatory and anti-inflammatory cytokines by immune cells which perfused adipose tissue (Monda $V$ et al, 2017). For these reasons, the accumulation of visceral fat creates a chronic low inflammation, elevate oxidative stress that leads to a development a cancer and immune diseases obesity correlates (Polito et al., 2018). Colorectal cancer is a type of cancer that strongly correlates to nutrition and obesity and it is know that among risk factors, weight excess has been suggested to positively influence dysplasia progression (Dore et al 2020; Messina G. et al, 2015). In this scenario, a healthy lifestyle, characterized by hypocaloric diet and physical activity, is important to reduce a chronic inflammation, oxidative stress and metabolic disorders typical of obesity (Bray et al., 2017). These are epigenetic factors which are able to reduce or prevent cancer process, reducing inflammation and oxidative stress (Nigro et al, 2018). DNA methylation is one of the most important epigenetic mechanisms of transcription control and plays a fundamental role in cell senescence, apoptosis and therefore in cancer (Horvath et al, 2018). A correct nutrition, adequate physical activity and abstention from smoking are important measures against aging and prevention of cardiovascular disease and cancer (Larsen et al, 2019). Data literature reported that physical activity reduces or slows the onset of diseases related to obesity, inducing a considerable weight loss and having beneficial and anti-inflammatory effects, reducing the production of free radicals, and favouring greater resistance to stress and prolonging lifespan (Carpagnano et al, 2020). Furthermore, a healthy lifestyle induces the expression of a many genes involved in the repair of cellular damage and reduces the expression of genes involved in the mechanisms of oxidative stress and inflammation (Nigro 2016). Data literature reported that a correct nutrition and regular physical activity are able to activate numerous metabolic pathways such as SIRT1 that deacetylates nuclear and cytoplasmic proteins that control apoptotic processes, and down-regulates the production of mediators of inflammation and reduces ROS production (Moro 2016, Chieffi 2017). Furthermore, constant physical activity is able to regulate in the skeletal muscle the production of pro and anti-inflammatory interleukins such as IL-6, IL-8 and IL-10 (Di Meo et al, 2019). In the light of these evidences, the aim of this study is to evaluate the effects of obese sera population before and after physical activity intervention on carcinoma cell line (HCT116) to demonstrate the beneficial effects of physical activity.

\section{MATERIAL AND METHODS}

\section{Participants}

Twenty obese subjects (10 females, 10 males), aged between 45-55 years (mean $52 \pm 2.5$ years), volunteered to participate in the study. Written informed consent for participation in the study was obtained from every patient. This study was performed in accordance with the Declaration of Helsinki and approved by the local ethics committee. Participants were excluded if they had a prior medical history of renal insufficiency, hyperuricemia, severe hepatic insufficiency, atrioventricular block, heart failure, cardiovascular and cerebrovascular diseases, unbalanced hypokalaemia, neoplasms, pregnancy and lactation. The anthropometric and biochemical characteristics of the 20 included patients are evaluated at baseline and after twelve months of physical activity program. Blood tests were taken at baseline and 6 months, after a $12 \mathrm{~h}$ fast. Fasting blood samples were collected at 8:00 am from an antecubital vein, using a 21G Vacutainer 
blood collection set (BD Diagnostics, Franklin Lakes, NJ, USA). Blood samples were centrifuged and the resultant serum stored at $-80^{\circ} \mathrm{C}$, until use.

\section{Physical activity protocol}

The obese subjects following this mixed exercise program. The protocol consist in 90 minutes per week in 2 session. In the first time obese subjects following an aerobic session, 20 minutes on treadmill $(60-80 \%$ of V02max). In the second step the patients are subjected to resistance exercise (65\% of 1RM). The protocol provides transverse thrust movements, frontal traction movements of the upper limbs, distension of the lower limbs, trunk flexions for the abdominals and 3 stretching positions. In addition, the participants underwent echocardiography and cardiopulmonary exercise testing at baseline and 6 months.

\section{Cell culture and cell proliferation assay}

The HCT116 Cell line, derived from human colon carcinoma, was purchased from the American Type Culture Collection (ATTC, LGC Standards srl, Italy). Cells were seeded at $4 \times 10^{3}$ cells/well in 96 well plates and cultured at $37^{\circ} \mathrm{C}$, in $5 \% \mathrm{CO}_{2}$ in DMEM (Sigma-Aldrich, Italy), supplemented with $2 \mathrm{mM}$ L-glutamine (SigmaAldrich, Italy), $100 \mathrm{U} / \mathrm{ml}$ penicillin/streptomycin and 10\% (v/v) FBS (Euroclone, Italy). Cultures were incubated at different time intervals (24h, $48 \mathrm{~h}$ and $72 \mathrm{~h}$ ) in the presence of either $5 \%(\mathrm{v} / \mathrm{v})$ pooled sera from obese subjects, collected prior and after physical activity intervention or $5 \%(\mathrm{v} / \mathrm{v})$ of FBS serum as control. As previously reported (Valenzano et al 2019) after 24h, 48h, $72 \mathrm{~h}$ incubation, cell viability was analysed by a Cell Proliferation Assay Kit (MTT- Sigma-Aldrich), following manufacturers' instructions. At the end of sera incubation, we added $10 \mu \mathrm{l}$ MTT labelling reagent and incubate the cells for $4 \mathrm{~h}$ at $37^{\circ} \mathrm{C}$ in a humidified atmosphere. At the end of $4 \mathrm{~h}$, we added $100 \mu \mathrm{l}$ of solubilization solution and incubate overnight at $37^{\circ} \mathrm{C}$ in a humidified atmosphere. After overnight incubation, we measure the spectrophotometrical absorbance of the samples using a microplate (ELISA) reader. The wavelength to measure absorbance of the formazan product is $550 \mathrm{~nm}$.

\section{RNA extraction and real-time PCR}

HCT116 cell line, after 12-h starvation, were treated in 5\% FBS medium as control and with 5\% pooled sera from obese subjects, collected prior and after physical activity intervention for $48 \mathrm{~h}$. After incubation, total RNA was isolated using TRIzol (Invitrogen, CA) and Real-time PCR was performed with appropriate primers for IL-6, IL-8, IL-10. The experiments were performed two times in triplicate.

\section{Statistical analysis}

Because this study used a "pre-post" design and the comparison of interest was the change from baseline to 12 months physical activity intervention, a two-tailed paired t test was used to test for statistical significance of outcome variables. Statistical analyses were performed using the StatView software 5.0.1.0. All data are presented as mean \pm SE. A p value of $\leq .05$ was used for statistical significance.

\section{RESULTS}

\section{Anthropometric and biochemical parameters of obese subjects before and after physical activity intervention}

Our results show a significant change in the anthropometric and biochemical parameters of obese subjects before and after physical activity intervention. First of all, anthropometric parameters such as weight and BMI are statistically reduced in obese subjects before and after physical activity (Table 1). Furthermore, there is a strongly modulation of all biochemical parameters, such as glycaemic and lipid profile. 
Table 1. Biochemical features of obese subjects before and after physical activity intervention.

\begin{tabular}{lccc}
\hline \multicolumn{4}{c}{ VLCKD obese subjects } \\
\hline Age & T0 & T1 & p-value \\
Height $(\mathrm{m})$ & $52 \pm 2.5$ & & $\mathrm{~ns}$ \\
Weight $(\mathrm{kg})$ & $1.70 \pm 0.11$ & $\mathrm{~ns}$ \\
BMl $\left(\mathrm{kg} / \mathrm{m}^{2}\right)$ & $92.33 \pm 17.11$ & $80.73 \pm 13.36$ & $<.001$ \\
Total Cholesterol $(\mathrm{mg} / \mathrm{dl})$ & $33.19 \pm 4.78$ & $27.76 \pm 3.62$ & $<.001$ \\
HDL $(\mathrm{mg} / \mathrm{dl})$ & $230.13 \pm 10.77$ & $153.91 \pm 12.3$ & $<.05$ \\
LDL $(\mathrm{mg} / \mathrm{dl})$ & $43.13 \pm 10.14$ & $46 \pm 9.14$ & $\mathrm{~ns}$ \\
Triglycerides $(\mathrm{mg} / \mathrm{dl})$ & $153 \pm 6.48$ & $106 \pm 7.72$ & $<.05$ \\
Insulinemia $(\mathrm{uUl} / \mathrm{ml})$ & $165.54 \pm 25.27$ & $93.25 \pm 26.14$ & $<.05$ \\
Total Protein $(\mathrm{g} / \mathrm{dl})$ & $10.3 \pm 7.18$ & $4.37 \pm 3.79$ & $<.05$ \\
AST-GOT $(\mathrm{U} / \mathrm{L})$ & $6.80 \pm 0.4$ & $7.13 \pm 0.4$ & $\mathrm{~ns}$ \\
ALT-GPT $(\mathrm{U} / \mathrm{L})$ & $21.27 \pm 5.98$ & $23.31 \pm 11.47$ & $<.05$ \\
Gamma GT $(\mathrm{U} / \mathrm{L})$ & $26.51 \pm 14.89$ & $26.06 \pm 16.27$ & $<.05$ \\
CRP mg/ml & $31.19 \pm 19.88$ & $15.31 \pm 5.41$ & $<.05$ \\
\hline
\end{tabular}

\section{MTT test}

To investigate which effects on cell viability the sera from obese subjects before and after physical activity, we treated $\mathrm{HCt} 116$ cells for $24 \mathrm{~h}, 48 \mathrm{~h}$ and $72 \mathrm{~h}$ with these sera and evaluated cell proliferation using the MTT assay kit. As control, we used cells incubated with $5 \%$ FBS. We found that sera from obese after physical activity intervention compared to treatment with sera from obese patients before physical activity intervention reduce the survival rate of HCT116.

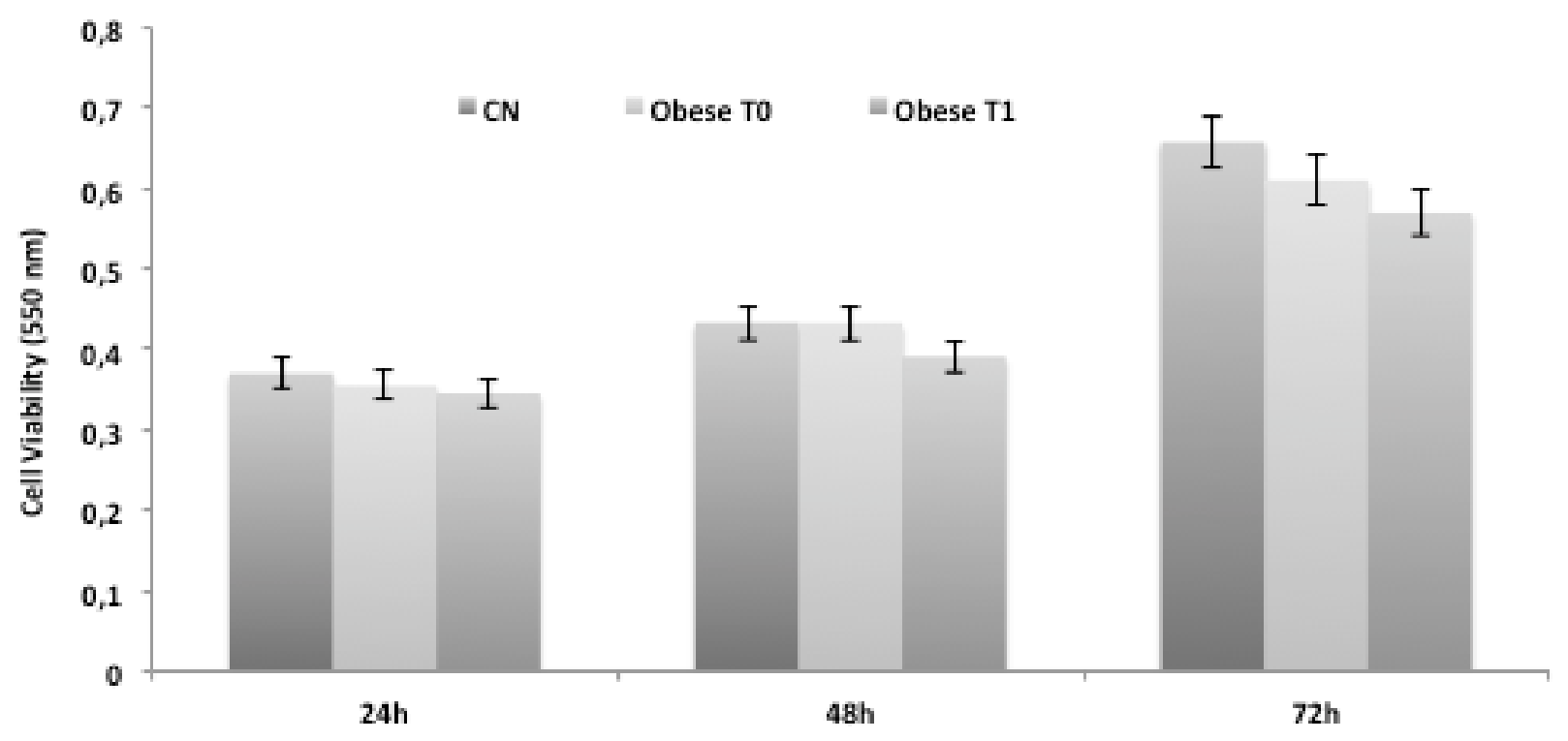

Figure 1. Obese sera after 6 months physical activity reduce survival rate of human carcinoma cell line (HCT116). 


\section{Pro-inflammatory and anti-inflammatory m-RNA levels in HCT116}

To investigate whether the treatment with obese sera regulates pro- and anti- inflammatory cytokines production in HCT116 cell line, we quantified the mRNA expression of IL-6, IL-8 and IL-10 after incubation of the cells with $5 \%$ of pooled obese sera before and after physical activity for $48 \mathrm{~h}$. We found that the treatment with pooled sera after physical activity intervention increased the expression of IL-10 $48 \mathrm{~h}$ of incubation (Figure 2) while decreases the expression of IL-6 and IL-8 after $48 \mathrm{~h}$ (Figure 2)

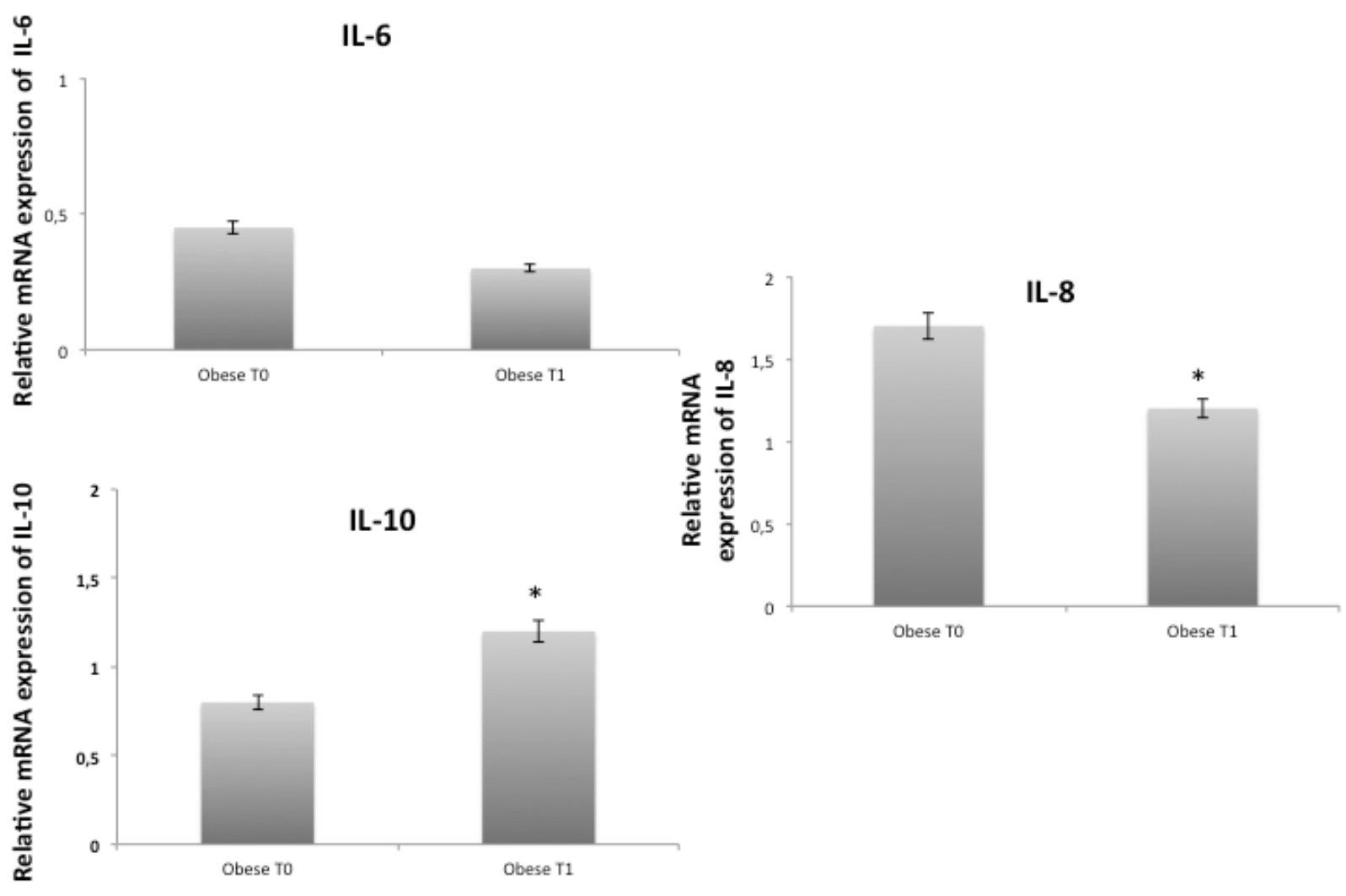

Figure 2. The treatment with obese sera after physical activity protocol induces IL-10 m-RNA expression and reduces IL-6 and IL-8 m-RNA expression in human carcinoma cell line (HCT116).

\section{DISCUSSION AND CONCLUSIONS}

Obesity is a chronic disease associated to insulin resistance, diabetes mellitus and altered lipid profile. In addition, obesity and obese-diseases correlated, lead to the development of many disease such as liver diseases, immune disease and cancer (Boutari et al., 2018, Messina et al, 2018). One of the characteristics of obesity is the accumulation of visceral fat mass, that is also a predictor of hyperinsulinemia and insulin resistance and responsible of chronic low-inflammation. (Viaggiano et al, 2009; Viggiano et al, 2016; Mahmoud et al., 2018). The visceral fat mass has an important role in the development of obesity. In obesity the strongly presence of visceral fat mass is responsible of an alteration of adipose tissue and its functions (Corbi et al, 2019). Indeed, the visceral fat mass creates a chronic low inflammation through an imbalance of the production of adipokines and cytokines by adipose tissue. For these reasons, the reduction of visceral adipose tissue leads to a decrease of chronic inflammation, blocking pro-inflammatory cytokines production and enhancing anti-inflammatory production (Di Zazzo et al, 2018). The strongly weight-loss and the 
reduction of BMI is associated also to the strongly reduction of visceral adipose tissue. Indeed, as reported by Moreno et al, the reduction of visceral fat leads to also reduce the risk of cardiovascular disease, diabetes, and even several kinds of cancer (Moreno et al., 2016). In particular, many data literature reported that the colon cancer is strongly associated with obesity and body weight (Dore et al, 2020). Furthermore, the production of pro-inflammatory cytokines is a characteristic of chronic low inflammation of obese subjects and is strongly involved also in oxidative stress and ROS production (Vicario et al, 2019; Di Mauro et al, 2019; Mauri et al, 2019). The obesity is a multifactorial disease, and it is evidenced that the healthy lifestyle represents the factor that have a major impact in its development. For these reasons, the diet and the physical activity is the epigenetic factors which has fast and important beneficial effects (Panico et al, 2017; Moscatelli et al, 2016; Moscatelli et al 2015; Sessa et al, 2018). Indeed, has reported by Francavilla et al, physical exercise protects against cardiovascular, bone and joint, and metabolic and inflammatory disorders such as colon cancer and that it is an effective means in the prevention and treatment of cancer (Francavilla $\mathrm{C}$ et al. 2013, Francavilla et al., 2015; Mazzeo et al, 2013). It follows than that physical well-being plays a central role in our lives. Physical activity improves cardiovascular performance and protects against many preventable diseases. We can consider the physical activity as a therapy in many metabolic and inflammatory disease and also in obesity and diseases correlated such as colon cancer (Francavilla et al, 2017; Patti et al 2017, Bianco et al., 2018). Indeed, as shown by our results, the treatment with obese sera after physical activity intervention strongly reduces human colon carcinoma cell line cell viability and pro-inflammatory cytokines m-RNA levels compared to obese subjects at baseline. On the contrary increased IL-10 m-RNA levels that is an anti-inflammatory mediator. Greco et al, reported that physical activity is able to activate the Nrf2/ARE system in both acute and chronic settings (Greco et al., 2016) reducing ROS production, increasing SOD 1 and SOD 2 and reduced pro-inflammatory cytokines production, increasing anti-inflammatory mediators production (Jornayvaz et al., 2010; Newsholme et al, 2016). In the light of these evidences, we can concluded that the physical activity has numerous beneficial effects also in colorectal cancer cell, indeed the physical activity and weight loss in obese subjects have an inhibitory and anti-inflammatory effects in a short period on carcinoma cell line, but further studies are needed to clarify the molecular mechanisms.

\section{REFERENCES}

Bianco A, Gentile A, Boca S, et al. (2018). An exploratory analysis of factors associated with healthrelated physical fitness in adolescents. Sustainability; 10:1847. https://doi.org/10.3390/su10061847

Boutari C, Perakakis N, Mantzoros CS. (2018). Association of Adipokines with Development and Progression of Nonalcoholic Fatty Liver Disease. Endocrinol Metab. 33(1):33-43. https://doi.org/10.3803/enm.2018.33.1.33

Bray G.A, Kim K.K, Wilding JPH. (2017). Obesity: a chronic relapsing progressive disease process. A position statement of the World Obesity Federation. Obes Rev. 18(7):715-723. https://doi.org/10.1111/obr.12551

Carpagnano GE, Sessa F, Scioscia G, Lacedonia D, Foschino MP, Venuti MP, Triggiani Al, Valenzano A, Resta O, Cibelli G, Messina G. (2020). Physical Activity as a New Tool to Evaluate the Response to Omalizumab and Mepolizumab in Severe Asthmatic Patients: A Pilot Study. Front Pharmacol.10:1630. https://doi.org/10.3389/fphar.2019.01630

Chieffi S, Carotenuto M, Monda V, Valenzano A, Villano I, Precenzano F, et al. (2017). Orexin System: The Key for a Healthy Life. Front. Physiol. 8:357. https://doi.org/10.3389/fphys.2017.00357

Corbi G, Polito R, Monaco ML, Cacciatore F, Scioli M, Ferrara N, Daniele A, Nigro E. (2019). Adiponectin Expression and Genotypes in Italian People with Severe Obesity Undergone a Hypocaloric Diet and Physical Exercise Program. Nutrients. 11(9). https://doi.org/10.3390/nu11092195 
Cristian V Francavilla, Francesco Sessa, Monica Salerno, Giuseppe D Albano, Ines Villano, et al. (2018). Influence of Football on Physiological Cardiac Indexes in Professional and Young Athletes. Front Physiol. 9:153. https://doi.org/10.3389/fphys.2018.00153

Di Mauro R, Cantarella G, Bernardini R, Di Rosa M, Barbagallo I, Distefano A, Longhitano L, Vicario N, Nicolosi D, Lazzarino G, Tibullo D, Gulino ME, Spampinato M, Avola R, Li Volti G. (2019). The Biochemical and Pharmacological Properties of Ozone: The Smell of Protection in Acute and Chronic Diseases. Int J Mol Sci. 20(3). pii: E634. https://doi.org/10.3390/ijms20030634

Di Meo S, Napolitano G, Venditti P. (2019). Mediators of Physical Activity Protection against ROS-Linked Skeletal Muscle Damage. Int J Mol Sci. 20(12). pii: E3024. https://doi.org/10.3390/ijms20123024

Di Zazzo E, Polito R, Bartollino S, Nigro E, Porcile C, Bianco A, Daniele A, Moncharmont B. (2019). Adiponectin as Link Factor between Adipose Tissue and Cancer. Int J Mol Sci. 20(4). pii: E839. https://doi.org/10.3390/ijms20040839

Dore MP, Longo NP, Manca A, Pes GM. (2020). The impact of body weight on dysplasia of colonic adenomas: a case-control study. Scand J Gastroenterol. 2020 Apr 1:1-6. https://doi.org/10.1080/00365521.2020.1746393

Francavilla G, Francavilla C. Physical exercise is therapy. MED SPORT 2013;66:625-8.

Francavilla VC, Bongiovanni T, Genovesi F, Minafra P, Francavilla G. (2015). Localized bioelectrical impedance analysis: how useful is it in the follow-up of muscle injury? A case report. MED SPORT; 68:323-34.

Francavilla VC, Bongiovanni T, Todaro L, Di Pietro V, Francavilla G. (2017). Probiotic supplements and athletic performance: a review of the literature. MED SPORT; 70:000-000. https://doi.org/10.23736/S0025-7826.17.03037-X

Greco T, Glenn T, Hoyda D, Prins LM. (2016). Ketogenic diet decreases oxidative stress and improves mitochondrial respiratory complex activity. J Cereb Blood Flow Metab. https://doi.org/10.1177/0271678x15610584

Horvath S, Raj K. (2018). DNA methylation-based biomarkers and the epigenetic clock theory of ageing. Nat Rev Genet. 19(6):371-384. https://doi.org/10.1038/s41576-018-0004-3

Jornayvaz FR, Jurczak MJ, Lee HY, Birkenfeld AL, Frederick DW, Zhang D, Zhang XM, Samuel VT, Shulman Gl. (2010). A high-fat, ketogenic diet causes hepatic insulin resistance in mice, despite increasing energy expenditure and preventing weight gain. Am. J. Physiol. Endocrinol. Metab. 299:E808-E815. https://doi.org/10.1152/ajpendo.00361.2010

Larsen S, Dandanell S, Kristensen KB, Jørgensen SD, Dela F, Helge JW. (2019). Influence of exercise amount and intensity on long-term weight loss maintenance and skeletal muscle mitochondrial ROS production in humans. Appl Physiol Nutr Metab. 44(9):958-964. https://doi.org/10.1139/apnm-20180577

Mahmoud Al-Dayyat , H., Rayyan, Y.M., Tayyem, R.F. (2018). Relationship of serum leptin with some biochemical, anthropometric parameters and abdominal fat volumes as measured by magnetic resonance imaging. Diabetes Metab Syndr, 22;12(3):207-213. https://doi.org/10.1016/i.dsx.2017.09.004

Mauri E, Sacchetti A, Vicario N, Peruzzotti-Jametti L, Rossi F, Pluchino S. (2018). Evaluation of RGD functionalization in hybrid hydrogels as 3D neural stem cell culture systems. Biomater Sci, 6(3):501510. https://doi.org/10.1039/c7bm01056g

Mazzeo F, Motti ML, Messina G, et al. (2013). Use of nutritional supplements among south Italian students of Physical Training and Sport University. Current Topics in Toxicology. 9:21-26.

Messina A, Bitetti I, Precenzano F, lacono D, Messina G, Roccella M, Parisi. et al. (2018). Non-Rapid Eye Movement Sleep Parasomnias and Migraine: A Role of Orexinergic Projections. Front Neurol.;9:95. https://doi.org/10.3389/fneur.2018.00095 
Messina A, Monda M, Valenzano A, Messina G, Villano I, Moscatelli F, Cibelli G, Marsala G, Polito R, Ruberto M, Carotenuto M, Monda V, Viggiano A, Daniele A, Nigro E. (2018). Functional Changes Induced by Orexin A and Adiponectin on the Sympathetic/Parasympathetic Balance. Front Physiol. 9:259. https://doi.org/10.3389/fphys.2018.00259

Messina A, Monda V, et al. (2017). Role of the orexin system on arousal, attention, feeding behaviour and sleep disorders. Acta Medica Mediterr. 33(4):645-64 https://doi.org/10.19193/03936384_2017_4_096

Messina G, Zannella C, Monda V, Dato A, Liccardo D, De Blasio S, Valenzano A, Moscatelli F, Messina A, Cibelli G and Monda M. (2015). The Beneficial Effects of Coffee in Human Nutrition. Biol Med. https://doi.org/10.4172/0974-8369.1000240

Monda V, La Marra M, Perrella R, Caviglia G, lavarone A, Chieffi S, Messina G, Carotenuto M, Monda M, Messina A. (2017). Obesity and brain illness: from cognitive and psychological evidences to obesity paradox. Diabetes Metab Syndr Obes.;10:473-479. https://doi.org/10.2147/dmso.s148392

Moreno B, Crujeiras AB, Bellido D, Sajoux I, Casanueva FF. (2016). Obesity treatment by very lowcalorie-ketogenic diet at two years: reduction in visceral fat and on the burden of disease. Endocrine. 3:681-690. https://doi.org/10.1007/s12020-016-1050-2

Moro T, Tinsley G, Bianco A, Marcolin G, Pacelli QF, Battaglia G, et al. (2016). Effects of eight weeks of time-restricted feeding (16/8) on basal metabolism, maximal strength, body composition, inflammation, and cardiovascular risk factors in resistance-trained males. J Transl Med. 13;14(1):290. https://doi.org/10.1186/s12967-016-1044-0

Moscatelli F, Messina G, Valenzano A, Monda M, et al. (2015). Relationship between RPE and Blood Lactate after Fatiguing Handgrip Exercise in Taekwondo and Sedentary Subjects. Biol Med. https://doi.org/10.4172/0974-8369.1000s3008

Moscatelli F, Messina G, Valenzano A, Monda V, Viggiano A, Messina A, Petito A, Triggiani Al, Ciliberti MA, Monda M, Capranica L, Cibelli G. (2016). Differences in corticospinal system activity and reaction response between karate athletes and non-athletes. Neurological Sciences. 37(12). https://doi.org/10.1007/s10072-016-2693-8

Newsholme P, Cruzat VF, Keane KN, Carlessi R, de Bittencourt PI Jr. (2016). Molecular mechanisms of ROS production and oxidative stress in diabetes. Biochem J. 473(24):4527-4550. https://doi.org/10.1042/bci20160503c

Nigro E, Sangiorgio D, Scudiero O, Monaco ML, Polito R, Villone G, Daniele A. (2016). Gene molecular analysis and Adiponectin expression in professional Water Polo players. Cytokine.; 81:88-93. https://doi.org/10.1016/i.cyto.2016.03.002

Nigro E, Schettino P, Polito R, Scudiero O, Monaco ML, De Palma GD, Daniele A. (2018). Adiponectin and colon cancer: evidence for inhibitory effects on viability and migration of human colorectal cell lines. Mol Cell Biochem. 448(1-2):125-135. https://doi.org/10.1007/s11010-018-3319-7

Panico A, Messina G, Lupoli GA, Lupoli R, Cacciapuoti M, Moscatelli F, Esposito T, Villano I, Valenzano A, Monda V, Messina A, Precenzano F, Cibelli G, Monda M, Lupoli G. (2017). Quality of life in overweight (obese) and normal-weight women with polycystic ovary syndrome. Patient Prefer Adherence. 11:423-429. https://doi.org/10.2147/ppa.s119180

Patti A, Bianco A, Karsten B, Montalto MA, Battaglia G, et al. (2017). The effects of physical training without equipment on pain perception and balance in the elderly: A randomized controlled trial. Work; 57:23-30. https://doi.org/10.3233/wor-172539

Polito R, Nigro E, Messina A, Monaco ML, Monda V, Scudiero O, Cibelli G, Valenzano A, Picciocchi E, Zammit C, Pisanelli D, Monda M, Cincione IR, Daniele A, Messina G. (2018). Adiponectin and Orexin-A as a Potential Immunity Link Between Adipose Tissue and Central Nervous System. Front Physiol.; 9:982. https://doi.org/10.3389/fphys.2018.00982 
Sessa F, Anna V, Messina G, Cibelli G, Monda V, Marsala G, Ruberto M, Biondi A, Cascio O, Bertozzi G, Pisanelli D, Maglietta F, Messina A, Mollica MP, Salerno M. (2018). Heart rate variability as predictive factor for sudden cardiac death. Aging; 23;10(2):166-177. https://doi.org/10.18632/aging.101386

Valenzano A, Polito R, Trimigno V, Di Palma A, Moscatelli F, Corso G, Sessa F, Salerno M, Montana A, Di Nunno N, Astuto M, Daniele A, Carotenuto M, Messina G, Cibelli G, Monda V. (2019). Effects of Very Low Calorie Ketogenic Diet on the Orexinergic System, Visceral Adipose Tissue, and ROS Production. Antioxidants. 8(12). pii: E643. https://doi.org/10.3390/antiox8120643

Vicario N, Pasquinucci L, Spitale FM, Chiechio S, Turnaturi R, Caraci F, Tibullo D, Avola R, Gulino R, Parenti R, Parenti C. (2019). Simultaneous Activation of Mu and Delta Opioid Receptors Reduces Allodynia and Astrocytic Connexin 43 in an Animal Model of Neuropathic Pain. Mol Neurobiol. 56(11):7338-7354. https://doi.org/10.1007/s12035-019-1607-1

Viggiano A, Vicidomini C, Monda M, Carleo D, Carleo R, Messina G, Viggiano A, Viggiano E, De Luca B. (2009). Fast and low-cost analysis of heart rate variability reveals vegetative alterations in noncomplicated diabetic patients. J Diabetes Complications. 23(2):119-23. https://doi.org/10.1016/j.jdiacomp.2007.11.009

Viggiano E, Monda V, Messina A, Moscatelli F, Valenzano A, Tafuri D, Cibelli G, De Luca B, Messina G, Monda M. (2016). Cortical spreading depression produces a neuroprotective effect activating mitochondrial uncoupling protein-5. Neuropsychiatr Dis Treat. 11;12:1705-10. https://doi.org/10.2147/ndt.s107074 